[Chem. Pharm. Bull.

35(1) $53-59$ (1987)

\title{
Structures of Sesquiterpenes from Curcuma aromatica SALISB.
}

\author{
Masanori Kuroyanagi, ${ }^{*}, a$ Akira Ueno, ${ }^{a}$ KaOru UjiIE ${ }^{a}$ \\ and SADAO SATO ${ }^{b}$ \\ Shizuoka College of Pharmacy, ${ }^{a}$ 2-2-1 Oshika, Shizuoka 422, Japan and \\ Analytical and Metabolic Research Laboratories, Sankyo Co., Ltd., ${ }^{b}$ \\ 1-2-58 Hiromachi, Shinagawa-ku, Tokyo 140, Japan
}

(Received June 5, 1986)

\begin{abstract}
Three new sesquiterpenes, isozedoarondiol (8), methylzedoarondiol (9) and neocurdione (10), were isolated along with germacrone (1), curdione (2), (4S,5S)-germacrone 4,5-epoxide (3), dehydrocurdione (4), procurcumenol (5), zedoarondiol (6) and curcumenone (7) from Curcuma aromatica SALISB. The absolute configuration of $\mathbf{6}$ was determined by X-ray analysis and chemical correlation with $\mathbf{3}$. The structures of $\mathbf{8 , 9}$ and $\mathbf{1 0}$ were also determined.
\end{abstract}

Keywords-Curcuma aromatica; sesquiterpene; germacrane-type sesquiterpene; guaianetype sesquiterpene; zedoarondiol; isozedoarondiol; neocurdione; $(4 S, 5 S)$-germacrone 4,5-epoxide; $\mathrm{X}$-ray analysis

Rhizomes of Curcuma spp. (Zingiberaceae), such as C. longa, C. zedoaria, C. xanthorhiza and $C$. aromatica, are used as oriental traditional medicines in China, Japan and southeastern Asia. From these plants, many kinds of sesquiterpenes have been isolated, but there have been few reports on the constituents of $C$. aromatica SALISB. ${ }^{11}$

The fresh rhizomes of the title plant, cultivated at the medicinal plants garden of this college, were extracted and treated as described in the experimental section to give three new sesquiterpenes, isozedoarondiol (8), methylzedoarondiol (9) and neocurdione (10), along with germacrone (1), curdione (2), (4S,5S)-germacrone 4,5-epoxide (3), dehydrocurdione (4), procurcumenol (5), zedoarondiol (6) and curcumenone (7). ${ }^{2}$ This paper deals with the isolation and structural elucidation of these sesquiterpenes. Further, the absolute configuration of $\mathbf{6}$ was determined by X-ray analysis and chemical derivatization from 3.

The proton and carbon-13 nuclear magnetic resonance $\left({ }^{1} \mathrm{H}\right.$ - and $\left.{ }^{13} \mathrm{C}-\mathrm{NMR}\right)$ spectra, and the other physicochemical data of $\mathbf{1}, \mathbf{3}, \mathbf{4}$ and 5 showed that these compounds were identical with germacrone, ${ }^{3)}(4 S, 5 S)$-germacrone 4,5 -epoxide, ${ }^{4)}$ dehydrocurdione ${ }^{5)}$ and procurcumenol, ${ }^{6)}$ respectively.

The spectral data of $2, \mathrm{mp} 61-62{ }^{\circ} \mathrm{C}, \mathrm{C}_{15} \mathrm{H}_{24} \mathrm{O}_{2}$, indicated that it was curdione, ${ }^{7)}$ and 2 was confirmed to be identical with an authentic sample. The ${ }^{1} \mathrm{H}$ - and ${ }^{13} \mathrm{C}-\mathrm{NMR}$ spectra of $\mathbf{1 0}$, mp $45-47^{\circ} \mathrm{C}, \mathrm{C}_{15} \mathrm{H}_{24} \mathrm{O}_{2}$, showed signal patterns similar to those of 2 , including three secondary methyl groups $[\delta 0.97(3 \mathrm{H}, \mathrm{d}, J=6.8 \mathrm{~Hz}), 1.03(3 \mathrm{H}, \mathrm{d}, J=6.8 \mathrm{~Hz}), 0.92(3 \mathrm{H}, \mathrm{d}, J=$ $6.6 \mathrm{~Hz})]$, a vinyl methyl group $[\delta 1.67(3 \mathrm{H}, \mathrm{s})]$, a tri-substituted olefin group $[\delta 5.18(\mathrm{H}, \mathrm{br} \mathrm{t}, J=$ $7.0 \mathrm{~Hz})]$ and two carbonyl groups $(\delta 210.2,212.5)$. These results indicated that $\mathbf{2}$ and $\mathbf{1 0}$ are diastereomers. The olefin groups of $\mathbf{2}$ and $\mathbf{1 0}$ were determined to be trans by nuclear Overhauser effect (NOE) experiments; in both compounds, irradiation at $9-\mathrm{CH}_{2}$ gave a $14 \%$ increase in the intensity of $1-\mathrm{H}$. Therefore, 2 and $\mathbf{1 0}$ might be epimers at C-4 or at C-7. The absolute structure of curdione has been reported as 2 . $^{7)}$ The circular dichroism (CD) spectra of $\mathbf{2}$ and $\mathbf{1 0}$ are shown in Fig. 1. Curdione and neocurdione showed opposite CD Cotton effects attributable to the $\beta, \gamma$-unsaturated ketone groups ${ }^{8)}$ (Fig. 1). An isopropyl group hàs a 


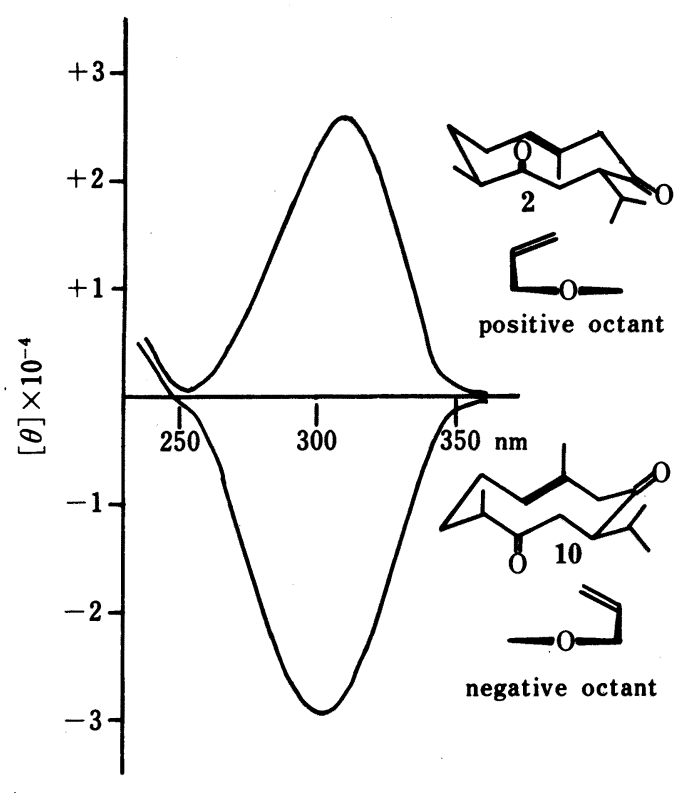

Fig. 1. CD Spectra of Curdione (2) and Neocurdione (10) in $\mathrm{CDCl}_{3}$

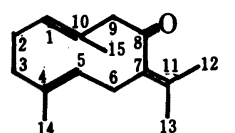

1
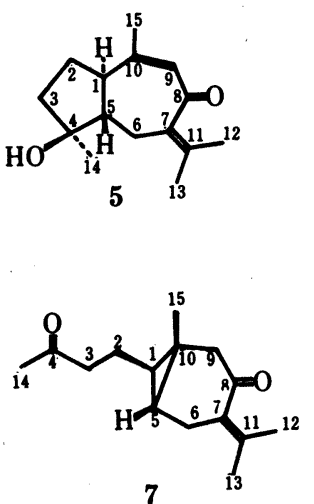<smiles>CC(C)CCC=C1CC(=O)CC(C(C)C)C(=O)C1</smiles>

2

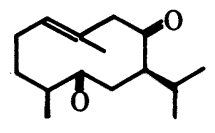

10<smiles>CC(C)=C(CC(=O)C(C)C)[C@H](O)C[C@@H]1CCCC(C)C1</smiles>

4<smiles>CC(C)[C@@H]1CC2OC2(C)CCC[C@@H]2CC(=O)[C@H]1C2</smiles>

3<smiles>CC(C)=C1C[C@]2(C)[C@H](O)CC[C@H]2[C@H](O)CC1=O</smiles><smiles>CC(C)=C1C[C@H]2[C@H](C)CC[C@H]2[C@H](C)OC1=O</smiles><smiles>CO[C@H]1CC(=O)[C@H](C(C)C)CC23CCC(O)[C@@]2(C)CC[C@H]13</smiles>

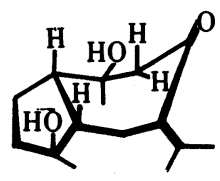

$8 \mathbf{a}$<smiles>CC(C)[C@@H]1C[C@H]2[C@@H](O)CC[C@H]2[C@H](O)CC1=O</smiles>

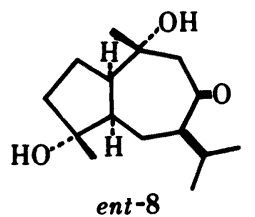

Chart 1

greater effect than a methyl group on the conformation so the isopropyl group at C-7 of 10 may have the opposite configuration from that of $2,{ }^{7)}$ but unequivocal confirmation is needed for the determination of the configurations at C-4 and C-7 of 10 .

The ${ }^{1} \mathrm{H}-\mathrm{NMR}$ spectrum of compound $7, \mathrm{mp} 28^{\circ} \mathrm{C}, \mathrm{C}_{15} \mathrm{H}_{22} \mathrm{O}_{2}$, showed that the structure of 7 was identical with that of curcumenone isolated from $C$. zedoaria by Asakawa et al. ${ }^{9)}$ The enantiomer of 7 has been isolated from Asarum caulescense MAXIM. ${ }^{10)}$ This secoguaiane-type compound having a cyclopropane ring is the secondary case after carabrone ${ }^{11)}$ isolated from Carpesium abrotanoides.

The ${ }^{1} \mathrm{H}$ - and ${ }^{13} \mathrm{C}-\mathrm{NMR}$ spectra of zedoarondiol (6), mp $134{ }^{\circ} \mathrm{C}, \mathrm{C}_{15} \mathrm{H}_{24} \mathrm{O}_{3},[\alpha]_{\mathrm{D}}-44.0^{\circ}$, showed the presence of two tertiary methyl groups $[\delta 1.18(\mathrm{~s}), 1.20(\mathrm{~s})$, and $20.6,22.7]$ on 
TABLE I. ${ }^{13}$ C-NMR Data for the Sesquiterpenes ${ }^{a)}$

\begin{tabular}{rrrrrrrrrrr}
\hline \hline & \multicolumn{1}{c}{$\mathbf{1}$} & \multicolumn{1}{c}{$\mathbf{2}$} & $\mathbf{3}$ & $\mathbf{4}$ & $\mathbf{5}$ & $\mathbf{6}$ & $\mathbf{7}$ & $\mathbf{8}$ & $\mathbf{9}$ & $\mathbf{1 0}$ \\
\hline C-1 & 132.5 & 131.5 & 129.7 & 132.7 & 50.5 & 55.9 & 29.8 & 53.4 & 51.6 & 131.1 \\
C-2 & 24.0 & 26.4 & 24.5 & 26.2 & 26.9 & 22.9 & 24.2 & 25.2 & 22.9 & 25.5 \\
C-3 & 38.0 & 34.1 & 37.7 & 34.1 & 28.6 & 28.5 & 43.8 & 27.4 & 28.7 & 32.8 \\
C-4 & 126.7 & 46.8 & 60.4 & 46.4 & 80.2 & 79.9 & 208.2 & 82.4 & 79.7 & 45.8 \\
C-5 & 125.4 & 211.0 & 64.3 & 210.6 & 54.0 & 52.0 & 24.3 & 51.7 & 48.4 & 210.2 \\
C-6 & 29.1 & 44.2 & 29.7 & 43.4 & 39.9 & 39.7 & 28.0 & 37.0 & 39.9 & 42.1 \\
C-7 & 129.0 & 53.5 & 126.7 & 129.4 & $136.6^{b)}$ & 134.6 & 128.0 & 134.0 & 135.0 & 52.6 \\
C-8 & 207.2 & 214.2 & 204.3 & 206.4 & 199.0 & 202.9 & 201.2 & 203.0 & 203.3 & 212.5 \\
C-9 & 55.8 & 55.9 & 55.4 & 56.8 & 129.2 & 59.8 & 48.9 & 50.2 & 53.9 & 55.3 \\
C-10 & 134.7 & 129.8 & 133.7 & 130.0 & $136.3^{b)}$ & 72.7 & 20.0 & 73.2 & 76.8 & 129.1 \\
C-11 & 137.3 & 30.0 & 133.9 & 136.9 & 155.1 & 142.1 & 146.9 & 143.7 & 141.5 & 30.9 \\
C-12 & 19.8 & $19.9^{b)}$ & 20.3 & 20.9 & 21.2 & 21.9 & 23.4 & 22.1 & 21.9 & $20.2^{b)}$ \\
C-13 & 22.2 & $21.1^{b)}$ & 22.6 & 22.0 & 22.4 & 22.2 & 23.4 & 22.8 & 22.2 & $21.1^{b)}$ \\
C-14 & 15.5 & $18.5^{b)}$ & 15.8 & 18.3 & 23.3 & 22.7 & 23.2 & 25.0 & 22.6 & $18.2^{b)}$ \\
C-15 & 16.6 & $16.6^{b)}$ & 17.0 & 16.2 & 24.3 & 20.6 & 18.9 & 32.2 & 17.1 & $18.2^{b)}$ \\
OMe & & & & & & & & & 53.4 & \\
\hline
\end{tabular}

a) Measured in $\mathrm{CDCl}_{3}$. b) Assignments may be interchanged in each column.

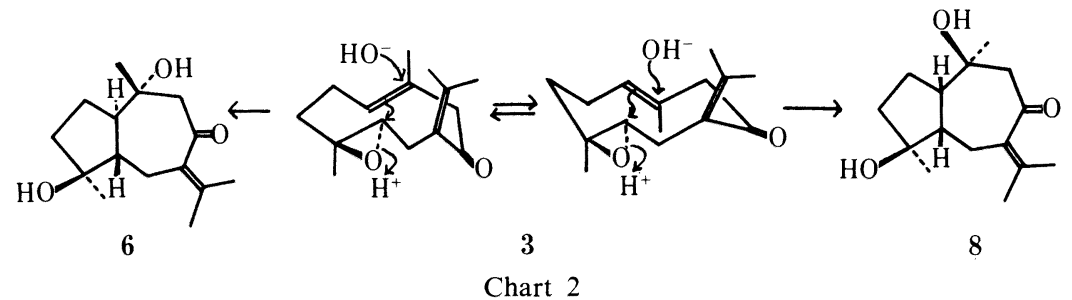

carbinyl carbons $(\delta 79.9,72.7)$, and an isopropylidene group $[\delta 1.84(\mathrm{~s}), 1.94(\mathrm{~s})$, and $21.9,22.2$, $134.6,142.1]$ conjugated with a carbonyl group $(\delta 202.9)$. The presence of conjugated enone system was supported by the ultraviolet (UV) spectrum $[\lambda 258 \mathrm{~nm}(3.86)]$. The ${ }^{1} \mathrm{H}-$ and ${ }^{13} \mathrm{C}$ NMR of isozedoarondiol (8), mp $150-156^{\circ} \mathrm{C}, \mathrm{C}_{15} \mathrm{H}_{24} \mathrm{O}_{3},[\alpha]_{\mathrm{D}}-147.2^{\circ}$, UV $252 \mathrm{~nm}$ (3.94), also showed the presence of the same functional groups as in $6[\delta 1.23(\mathrm{~s}), 1.42(\mathrm{~s}), 1.86(\mathrm{~s})$, 2.03 (s), and 22.1, 22.8, 25.0, 32.2, 134.0, 143.7, 203.0] $\left({ }^{13} \mathrm{C}-\mathrm{NMR}\right.$ data for $\mathbf{6}$ and $\mathbf{8}$ are listed in Table I). These data suggested that 6 and 8 had the same plane structure, having a guaianetype skeleton, and might be diastereomers. From the transannular cyclization reaction mechanism, $\mathbf{6}$ and $\mathbf{8}$ should be formed from $\mathbf{3}$ as shown in Chart 2.

To elucidate the relative stereostructure of 6, X-ray analysis was carried out. The X-ray crystallographical data are ás follows: $\mathrm{C}_{15} \mathrm{H}_{24} \mathrm{O}_{3}, M_{\mathrm{r}}=252.4$, monoclinic, $P 2_{1}, a=9.397(1)$, $b=8.405(1), c=10.201(2) \AA, \beta=110.44(1)^{\circ}, U=754.9 \AA^{3}, Z=2, D_{x}=1.11 \mathrm{~g} \cdot \mathrm{cm}^{-3}$. Intensity data to $\theta=64^{\circ}$ were recorded on a Rigaku AFC-5R diffractometer, using graphitemonochromated $\mathrm{Cu} K_{\alpha}$ radiation. A total of 1346 independent reflections were corrected for Lorentz and polarization factors but not for absorption. The structure was solved by MULTAN $^{12)}$ and refined by block-diagonal least-squares methods. Hydrogen atoms were located in difference syntheses. The final least-squares refinement with anisotropic temperature factors for the non-hydrogen atoms and isotropic temperature factors for the hydrogen atoms lowered the $R$-value to 0.076 for 1153 observed reflections $\left(F_{\mathrm{o}} 2 \sigma F_{\mathrm{o}}\right)$.

The geometry of the molecule thus obtained is shown in Fig. 2 with the atomic numbering. Compound $\mathbf{6}$ is biosynthesized from $\mathbf{3}$ in the plant. Zedoarondiol was formed 


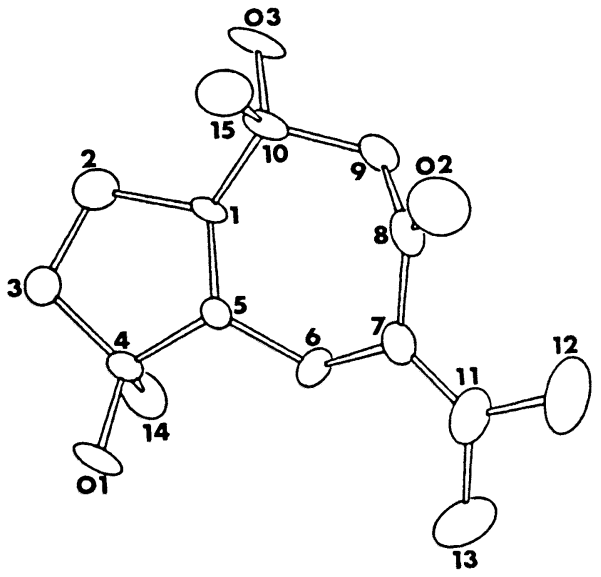

Fig. 2. A Perspective Drawing of 6

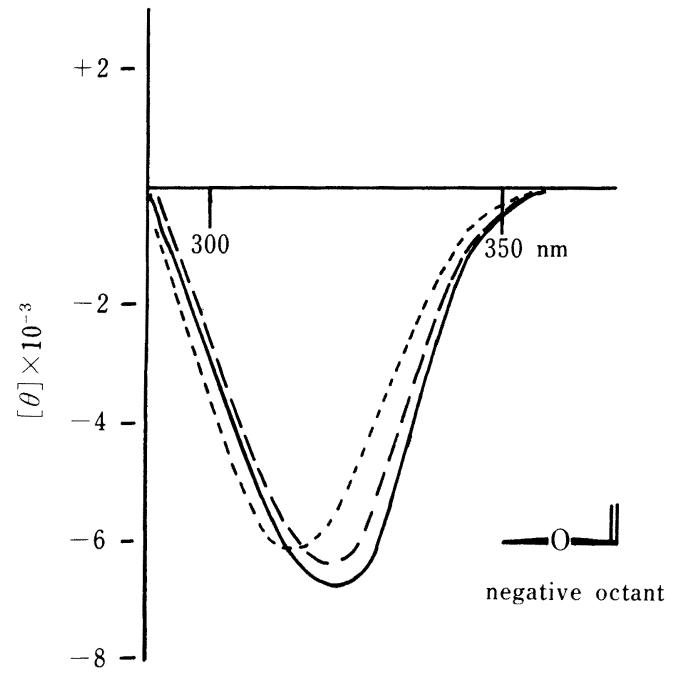

Fig. 3. CD Spectra of Zedoarondiol (6), Isozedoarondiol (8) and Methylzedoarondiol (9) in $\mathrm{MeOH}$

6, ---; 8, -.--; 9,

from 3 along with 8 by treatment with $\mathrm{H}_{2} \mathrm{SO}_{4}$ in dioxane-water. Thus, its absolute configuration is that shown in $\mathbf{6}$.

The five-membered ring occurs in an envelope conformation with $C(4)$ as the flap at -0.65 (4) $\AA$ out of the best plane formed by the other four atoms. The fusion to the sevenmembered ring is trans with torsion angles of $30.0(9)^{\circ}$ and $-76.0(10)^{\circ}$ for $\mathrm{C}(4)-\mathrm{C}(5)-\mathrm{C}(1)-$ $\mathrm{C}(2)$ and $\mathrm{C}(10)-\mathrm{C}(1)-\mathrm{C}(5)-\mathrm{C}(6)$, respectively. The seven-membered ring has a twist-chair conformation. The torsion angles agree well with the theoretical values for the twist-chair form of the cycloheptane ring. ${ }^{13)}$ The two hydroxyl groups attached to $\mathrm{C}(4)$ and $\mathrm{C}(10)$ are cis with respect to the neighboring bridgehead $\mathrm{H}$ atom, and participate in intermolecular hydrogen bonds: $\mathrm{O}(1) \quad \mathrm{H} \cdots \mathrm{O}(2) \quad(\mathrm{O}(1) \cdots \mathrm{O}(2)=2.810(11) \AA)$ and $\mathrm{O}(3) \mathrm{H} \cdots \mathrm{O}(1)$ $(\mathrm{O}(3) \cdots \mathrm{O}(1)=2.826(10) \AA)$, respectively.

The ${ }^{1} \mathrm{H}-\mathrm{NMR}$ spectrum of $\mathbf{6}$ showed the presence of a long-range coupling between 15 $\mathrm{CH}_{3}[\delta 1.18(3 \mathrm{H}, \mathrm{s})]$ and $9 \alpha-\mathrm{H}[\delta 2.98(\mathrm{H}, \mathrm{d}, J=13.0 \mathrm{~Hz})]$, which was confirmed by a decoupling experiment. Thus, $15-\mathrm{CH}_{3}$ was decoupled to sharpen the broad doublet of $9 \alpha-\mathrm{H}$, while $9 \alpha-\mathrm{H}$ was decoupled to increase the height of the $15-\mathrm{CH}_{3}$ signal. The $\mathrm{CD}$ spectrum of 6 showed a negative Cotton effect (Fig. 3) $\left([\theta]_{321}-6463\right)$ attributed to $n \rightarrow \pi^{*}$ transition of an $\alpha, \beta$-unsaturated ketone. ${ }^{14)}$ These data accord with the absolute structure obtained from the $\mathrm{X}$ ray analysis (Fig. 2). The ${ }^{1} \mathrm{H}-\mathrm{NMR}$ spectrum of $\mathbf{8}$ showed the presence of long-range coupling between $15-\mathrm{CH}_{3}[\delta 1.42(3 \mathrm{H}, \mathrm{s})]$ and $9 \beta-\mathrm{H}[\delta 2.42(\mathrm{H}, \mathrm{d}, J=16.0 \mathrm{~Hz})]$. The CD spectrum of 8 also showed negative Cotton effect (Fig. 3) $\left([\theta]_{313}-6323\right)$. These data suggested that the absolute configuration of isozedoarondiol is $\mathbf{8}$ and its conformation might be as shown in $\mathbf{8 a}$, having an antiparallel relationship between $15-\mathrm{CH}_{3}$ and $9 \beta-\mathrm{H}$, and anticlockwise helicity of the conjugated enone system.

Endo and Itokawa ${ }^{10)}$ isolated the ent-type compounds $\mathbf{6}$ and $\mathbf{8}$, from $A$. caulescens MAXIM. The ${ }^{1} \mathrm{H}-\mathrm{NMR}$ data and infrared (IR) data of $\mathbf{6}$ and 8 were identical with those of ent6 and ent-8, but the optical properties, such as optical rotations and CD spectra, were opposite. The structures of ent-6 and ent-8 have been reported to be the interchanged structures, so they should be revised as shown in Chart 1 .

Methylzedoarondiol (9), mp $83-85^{\circ} \mathrm{C}, \mathrm{C}_{16} \mathrm{H}_{26} \mathrm{O}_{3}$, showed the presence of a methoxyl 
group $[\delta 3.20(3 \mathrm{H}, \mathrm{s})$ and 51.9] and the same functional groups as those of 6 (Table I), which indicated that 9 was a mono-methylether of 6 . In the ${ }^{1} \mathrm{H}-\mathrm{NMR}$ spectrum, the carbon at $\mathrm{C}-10$ was shifted to lower field and the carbons at C-1 and C-9 were shifted to higher field compared with those of $6(\delta 72.7 \rightarrow 76.8$ for C-10, 55.9 $\rightarrow 51.9$ for C-1 and $59.8 \rightarrow 53.9$ for C-9, respectively). Other carbon signals were almost the same as those of 6 . These results indicated that the structure of 9 was the methyl ether of 6 at C-10. Methylzedoarondiol also showed the same negative optical rotation $\left([\alpha]_{D}-43.1^{\circ}\right)$ and $C D$ spectrum (Fig. 3) $\left([\theta]_{322}-6742\right)$ as 6. Further, 9 was derived from 3 by treatment with $\mathrm{H}_{2} \mathrm{SO}_{4} / \mathrm{MeOH}$. The synthetic 9 was identical with the natural one $\left({ }^{1} \mathrm{H}-\mathrm{NMR},{ }^{13} \mathrm{C}-\mathrm{NMR}\right.$, thin layer chromatography (TLC), highperformance liquid chromatography (HPLC) and optical rotation).

Kawano and Kouno isolated zedoarondiol, ${ }^{15)}$ from $C$. zedoaria, but the optical properties have not been reported. From $C$. zedoaria, $(4 S, 5 S)$-germacrone 4,5-epoxide (3) has also been isolated, so the absolute configuration of zedoarondiol, isolated by Kawano and Kouno might be identical with that of $\mathbf{6}$, isolated from $C$. aromatica.

The biogenetic pathway of these sesquiterpenes, isolated from $C$. aromatica, was considered to be as follows, $(4 S, 5 S)$-germacrone 4,5 -epoxide (3) acts as a key intermediate in the pathway. Germacrone (1) is epoxidated to give the key intermediate (3). Then hydrolysis and dehydration of 3 give dehydrocurdione (4), which is further hydrogenated to give curdione (2) and neocurdione (10). On the other hand $\mathbf{3}$ is also transformed by transannular cyclization via a cationic intermediate to procurcumenol (5), zedoarondiol (6), isozedoarondiol (8), methylzedoarondiol (9) and curcumenone (7).

\section{Experimental}

All melting points were determined on a Yanagimoto micro melting point apparatus and are uncorrected. IR spectra were recorded on a JASCO A-202 grating infrared spectrometer. UV spectra were recorded on a Hitachi model 200-10 spectrometer. Optical rotations were recorded on a JASCO DIP-140 digital polarimeter. CD spectra were recorded on a JASCO J-20A spectropolarimeter. ${ }^{1} \mathrm{H}$ - and ${ }^{13} \mathrm{C}-\mathrm{NMR}$ spectra were recorded on a JEOL JNM-FX $90 \mathrm{Q}$ NMR spectrometer with tetramethylsilane as an internal standard ( $\delta$ value, ppm). Mass spectra (MS) were recorded on JEOL JMS D-100 and JEOL JMS 01SG-2 mass spectrometers. TLC was performed on precoated Silica gel $60 \mathrm{~F}_{254}$ plates (Merck). Preparative thin layer chromatography (PTLC) was performed on Silica gel $\mathrm{PF}_{254}(\mathrm{Merck}$ $200 \times 200 \times 0.7 \mathrm{~mm}$ ). Column chromatography was performed on Silica gel type 60 (Merck).

Isolation of the Constituents - The fresh rhizomes of $C$. aromatica $(2 \mathrm{~kg}$ ) were extracted with $\mathrm{MeOH}$ at room temperature to give the $\mathrm{MeOH}$ extract. The residue was extracted with chloroform $\left(\mathrm{CHCl}_{3}\right)$ at room temperature to give the $\mathrm{CHCl}_{3}$ extract. The $\mathrm{MeOH}$ extract was suspended in water and extracted with $\mathrm{CHCl}_{3}$ to give the $\mathrm{CHCl}_{3}$-soluble fraction. The $\mathrm{CHCl}_{3}$ fraction and $\mathrm{CHCl}_{3}$ extract were combined to give the $\mathrm{CHCl}_{3}$-soluble extract $(37 \mathrm{~g})$. The extract was chromatographed on a silica gel column using a benzene-ethyl acetate (AcOEt) gradient solvent system to give five fractions, Fr. I (3.8 g), II (10.2 g), III (5.4 g), IV (5.9 g) and V (6.2 g). Fraction II was chromatographed on a silica gel column using the hexane-AcOEt gradient solvent system to give germacrone (1) $(550 \mathrm{mg})$, curdione (2) $(720 \mathrm{mg})$ and $(4 S, 5 S)$-germacrone 4,5-epoxide (3) (300 mg). Fraction III was chromatographed on a silica gel column using the same solvent system to give dehydrocurdione (4) $(90 \mathrm{mg})$, neocurdione (10) (150 mg) and curcumenone (7) $(800 \mathrm{mg})$. Fraction IV was repeatedly chromatographed on a silica gel column using $\mathrm{CHCl}_{3}-$ $\mathrm{MeOH}$ gradient and hexane-AcOEt gradient solvent systems to give procurcumenol (5) (210 mg) and methylzedoarondiol (9) (160 mg). Fraction $\mathrm{V}$ was chromatographed on a silica gel column using the $\mathrm{CHCl}_{3}-\mathrm{MeOH}_{\text {gradient }}$ solvent system, followed by PTLC using benzene-AcOEt-MeOH $(2: 2: 1)$ to give zedoarondiol (6) (250 mg) and

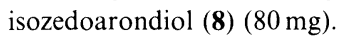

Germacrone (1): Colorless prisms. mp 53-54 $\mathrm{C}(\mathrm{MeOH}) . \mathrm{MS} m / z: 218\left(\mathrm{M}^{+}\right)\left(\mathrm{C}_{15} \mathrm{H}_{22} \mathrm{O}\right) . \mathrm{IR} v_{\max }^{\mathrm{KBr}} \mathrm{cm}^{-1}: 1679$, $1665,1445,1294,1135,{ }^{13} \mathrm{C}-\mathrm{NMR}$ was shown in Table I.

Curdione (2): Colorless prisms. mp 61-62 C (pet. ether). MS $m / z: 236\left(\mathrm{M}^{+}\right)\left(\mathrm{C}_{15} \mathrm{H}_{24} \mathrm{O}_{2}\right) . \mathrm{IR} v_{\max }^{\mathrm{KBr}} \mathrm{cm}^{-1}: 1690$, $1460,1420,1170,1060 .[\alpha]_{\mathrm{D}}^{23}+214.0^{\circ}(c=1.6, \mathrm{MeOH}) . \mathrm{CD}\left(c=0.033, \mathrm{CHCl}_{3}\right):[\theta]_{309}+26655 .{ }^{13} \mathrm{C}-\mathrm{NMR}$ data are shown in Table I.

(4S,5S)-Germacrone 4,5-Epoxide (3): Colorless prisms. mp 63.5-64 C (hexane). $\mathrm{MS} m / z$ : $234\left(\mathrm{M}^{+}\right)$ $\left(\mathrm{C}_{15} \mathrm{H}_{22} \mathrm{O}_{2}\right) \cdot[\alpha]_{\mathrm{D}}^{23}+306.1^{\circ}(c=0.5, \mathrm{MeOH}) . \mathrm{IR} v_{\max }^{\mathrm{KBr}} \mathrm{cm}^{-1}: 1710,1694,1662,1440,1250 . \mathrm{CD}(c=0.006, \mathrm{MeOH}):$ $[\theta]_{309}+14900,[\theta]_{253}+14900,[\theta]_{227}-13590 .{ }^{13} \mathrm{C}-\mathrm{NMR}$ data are shown in Table $\mathrm{I}$.

Dehydrocurdione (4): Colorless needles. mp $40-42^{\circ} \mathrm{C}$ (hexane). $\mathrm{MS} m / z: 234\left(\mathrm{M}^{+}\right)\left(\mathrm{C}_{15} \mathrm{H}_{22} \mathrm{O}_{2}\right) \cdot[\alpha]_{\mathrm{D}}^{23}+147.5^{\circ}$ 
$(c=1.1, \mathrm{MeOH}) . \mathrm{CD}(c=0.004, \mathrm{MeOH}):[\theta]_{303}+13671 .{ }^{13} \mathrm{C}-\mathrm{NMR}$ data are shown in Table I.

Procurcumenol (5): Viscous oil. MS $m / z: 234\left(\mathrm{M}^{+}\right)\left(\mathrm{C}_{15} \mathrm{H}_{22} \mathrm{O}_{2}\right)$. IR $v_{\max }^{\text {liq }} \mathrm{cm}^{-1}: 3430,1650,1440,1377 .[\alpha]_{D}^{23}$ $+60.9^{\circ}\left(c=0.8, \mathrm{CHCl}_{3}\right) .{ }^{13} \mathrm{C}-\mathrm{NMR}$ data are shown in Table I.

Zedoarondiol (6): Colorless needles. mp $134^{\circ} \mathrm{C}\left(\mathrm{CHCl}_{3}\right)$. MS $m / z: 252\left(\mathrm{M}^{+}\right)\left(\mathrm{C}_{15} \mathrm{H}_{24} \mathrm{O}_{3}\right) \cdot \mathrm{IR} v_{\max }^{\mathrm{KBr}} \mathrm{cm}^{-1}: 3420$, 1662, 1604. UV $\lambda_{\max }^{\mathrm{MeOH}} \mathrm{nm}(\log \varepsilon): 258(3.86) \cdot[\alpha]_{\mathrm{D}}^{23}-44^{\circ}(c=1.0, \mathrm{MeOH}) . \mathrm{CD}(c=0.03, \mathrm{MeOH}):[\theta]_{321}-6468 .{ }^{1} \mathrm{H}-$ NMR $\left(\mathrm{CDCl}_{3}\right): 1.18\left(3 \mathrm{H}, \mathrm{s}, 14\right.$ or $\left.15-\mathrm{CH}_{3}\right), 1.20\left(3 \mathrm{H}, \mathrm{s}, 15\right.$ or $\left.14-\mathrm{CH}_{3}\right), 1.84\left(3 \mathrm{H}, \mathrm{s}, 12\right.$ or $\left.13-\mathrm{CH}_{3}\right), 1.94(3 \mathrm{H}, \mathrm{s}, 13$ or 12- $\left.\mathrm{CH}_{3}\right), 2.60(\mathrm{H}, \mathrm{d}, J=13.0 \mathrm{~Hz}, 9 \beta-\mathrm{H}), 2.98(\mathrm{H}, \mathrm{d}, J=13.0 \mathrm{~Hz}, 9 \alpha-\mathrm{H}) .{ }^{13} \mathrm{C}-\mathrm{NMR}$ data are shown in Table I.

Curcumenone (7): Colorless needles. $\mathrm{mp} 28^{\circ} \mathrm{C}$ (hexane). $\mathrm{MS} m / z: 234.1621\left(\mathrm{M}^{+}\right)$(Calcd. for $\mathrm{C}_{15} \mathrm{H}_{22} \mathrm{O}_{2}$ 234.1618). IR $v_{\max }^{\mathrm{KBr}} \mathrm{cm}^{-1}: 1718,1675,1600,1360,1170$. UV $\lambda_{\max }^{\mathrm{MeOH}} \mathrm{nm}(\log \varepsilon): 234(3.82)$. $[\alpha]_{\mathrm{D}}^{23}-6.1^{\circ}(c=0.5, \mathrm{MeOH})$. $\mathrm{CD}(c=0.007, \mathrm{MeOH}):[\theta]_{314}+1884 .{ }^{13} \mathrm{C}-\mathrm{NMR}$ data are shown in Table I.

Isozedoarondiol (8): Colorless needles. $\mathrm{mp} 150-156^{\circ} \mathrm{C}\left(\mathrm{CHCl}_{3}\right) . \mathrm{IR} v_{\max }^{\mathrm{KBr}} \mathrm{cm}^{-1}: 3500,3330,1662,1598,1378$, 1304, 1170. UV $\lambda_{\max }^{\mathrm{MeOH}} \mathrm{nm}(\log \varepsilon): 252(3.94) .[\alpha]_{\mathrm{D}}^{23}-147.2^{\circ}(c=0.8, \mathrm{MeOH}) . \mathrm{CD}(c=0.003, \mathrm{MeOH}):[\theta]_{313}-6323$. Anal. Calcd for $\mathrm{C}_{15} \mathrm{H}_{24} \mathrm{O}_{3}$ : C, 71.39; H, 9.59. Found: C, 71.65; H, 9.52. ${ }^{1} \mathrm{H}-\mathrm{NMR}\left(\mathrm{CDCl}_{3}\right): 1.23\left(3 \mathrm{H}, \mathrm{s}, 14-\mathrm{CH}_{3}\right), 1.42$ $\left(3 \mathrm{H}, \mathrm{s}, 15-\mathrm{CH}_{3}\right), 1.86\left(3 \mathrm{H}, \mathrm{s}, 12\right.$ or $\left.13-\mathrm{CH}_{3}\right), 2.03\left(3 \mathrm{H}, \mathrm{s}, 13\right.$ or $\left.12-\mathrm{CH}_{3}\right), 2.42(\mathrm{H}, \mathrm{d}, J=16.0 \mathrm{~Hz}, 9 \beta-\mathrm{H}), 3.21(\mathrm{H}, \mathrm{d}, J=$ 16.0 Hz, $9 \alpha-\mathrm{H}) .{ }^{13} \mathrm{C}-\mathrm{NMR}$ data are shown in Table $\mathrm{I}$.

Methylzedoarondiol (9): Colorless needles, $\mathrm{mp} 83-85^{\circ} \mathrm{C}$ (hexane). IR $v_{\max }^{\mathrm{KBr}} \mathrm{cm}^{-1}: 3330,3300,1676,1652,1579$, 1300. $[\alpha]_{\mathrm{D}}^{23}-43.1^{\circ}(c=0.2, \mathrm{MeOH}) . \mathrm{CD}(c=0.007, \mathrm{MeOH}):[\theta]_{322}-6742$. Anal. Calcd for $\mathrm{C}_{16} \mathrm{H}_{26} \mathrm{O}_{3}: \mathrm{C}, 72.14 ; \mathrm{H}$, 9.84. Found: C, $72.29 ; \mathrm{H}, 9.89 .{ }^{1} \mathrm{H}-\mathrm{NMR}\left(\mathrm{CDCl}_{3}\right): 1.12\left(3 \mathrm{H}, \mathrm{s}, 14\right.$ or $\left.15-\mathrm{CH}_{3}\right), 1.20\left(3 \mathrm{H}, \mathrm{s}, 15\right.$ or $\left.14-\mathrm{CH}_{3}\right), 1.84(3 \mathrm{H}, \mathrm{s}$, 12 or $\left.13-\mathrm{CH}_{3}\right), 1.95\left(3 \mathrm{H}, \mathrm{s}, 13\right.$ or $\left.12-\mathrm{CH}_{3}\right), 3.20(3 \mathrm{H}, \mathrm{s}, \mathrm{OMe}) .{ }^{13} \mathrm{C}-\mathrm{NMR}$ data are shown in Table I.

Neocurdione (10): Colorless needles. $\mathrm{mp} 45-47^{\circ} \mathrm{C}$ (hexane). $\mathrm{MS} m / z: 236.1763\left(\mathrm{M}^{+}\right)\left(\mathrm{Calcd}\right.$ for $\mathrm{C}_{15} \mathrm{H}_{24} \mathrm{O}_{2}$ 236.1777). IR $v_{\max }^{\mathrm{KBr}} \mathrm{cm}^{-1}: 1696,1682,1395,1282$. UV $\lambda_{\max }^{\mathrm{MeOH}} \mathrm{nm}(\log \varepsilon): 203(3.73) .[\alpha]_{\mathrm{D}}^{23}-190.6^{\circ}\left(c=2.1, \mathrm{CHCl}_{3}\right) . \mathrm{CD}$ $(c=0.022, \mathrm{MeOH}):[\theta]_{301}-29230 .{ }^{1} \mathrm{H}-\mathrm{NMR}\left(\mathrm{CDCl}_{3}\right): 0.92\left(3 \mathrm{H}, \mathrm{d}, J=6.6 \mathrm{~Hz}, 14-\mathrm{CH}_{3}\right), 0.98(3 \mathrm{H}, \mathrm{d}, J=6.8 \mathrm{~Hz}, 12$ or $\left.13-\mathrm{CH}_{3}\right), 1.03\left(3 \mathrm{H}, \mathrm{d}, J=6.8 \mathrm{~Hz}, 13\right.$ or $\left.12-\mathrm{CH}_{3}\right), 1.67\left(3 \mathrm{H}, \mathrm{s}, 15-\mathrm{CH}_{3}\right), 5.18(1 \mathrm{H}, \mathrm{brt}, J=7.0 \mathrm{~Hz}) .{ }^{13} \mathrm{C}-\mathrm{NMR}$ data are shown in Table I.

Transformation from 3 to 10 - One drop of conc. $\mathrm{H}_{2} \mathrm{SO}_{4}$ was added to $280 \mathrm{mg}$ of 3 in $\mathrm{MeOH}(4 \mathrm{ml})$. The reaction solution was stirred for $1 \mathrm{~h}$ at room temperature. The reaction solution was poured into ice-water and extracted with $\mathrm{CHCl}_{3}$. The $\mathrm{CHCl}_{3}$ solution was dried and evaporated. The reaction products were purified by PLC to give $9(80 \mathrm{mg})$, which was identical with the natural compound in terms of spectra.

Transformation from 3 to 6 and 8 - One drop of conc. $\mathrm{H}_{2} \mathrm{SO}_{4}$ was added to $234 \mathrm{mg}$ of 3 in dioxane ( $\left.2 \mathrm{ml}\right)$ and water $(2 \mathrm{ml})$. The solution was stirred for $4 \mathrm{~h}$ at room temperature. The reaction solution was poured into ice-water and extracted with $\mathrm{CHCl}_{3}$. The $\mathrm{CHCl}_{3}$ solution was dried and evaporated. The reaction products were purified with PTLC to give $6(19 \mathrm{mg})$ and $8(15 \mathrm{mg})$. The synthetic 6 and 8 were identical with the natural compounds in terms of TLC behavior, ${ }^{1} \mathrm{H}-\mathrm{NMR}$ signals and optical rotation.

Acknowledgements We wish to thank Dr. A. Ogiso, Sankyo Co., Ltd., and Dr. K. Yoshihira, National Institute of Hygienic Sciences, for their valuable suggestions, and Prof. S. Inayama, Pharmaceutical Institute, School of Medicine, Keio University, for the identification of curdione and valuable discussions. We also thank Dr. M. Uchida and Mrs. H. Kitamura of the Analysis Center of this College for mass spectral measurement and elemental analysis.

\section{References}

1) R. Hegnauer "Chemotaxonomie der Pflanzen," Band II, Birkhauser Verlag Basel und Stuttgart, 1963, p. 451.

2) M. Kuroyanagi, K. Ujiie, S. Fukushima and K. Nishi, Abstracts of Papers, 31st Annual Meeting of the Japanese Society of Pharmacognosy, Tokyo, 1984, p. 55; M. Kuroyanagi, K. Ujiie, A. Ueno, S. Fukushima and K. Nishi, Symposium Papers, 29th Symposium on the Chemistry of Terpenes, Essential Oils and Aromatics, Mie, 1985, p. 268.

3) F. Bohlmann and C. Zdero, Chem. Ber., 106, 3614 (1973).

4) M. Yoshihara, H. Shibuya, E. Kitano, K. Yanagi and I. Kitagawa, Chem. Pharm. Bull., 32, 2059 (1984).

5) H. Hikino, C. Konno and T. Takemoto, Chem. Pharm. Bull., 20, 987 (1972).

6) H. Hikino, Y. Sakurai and T. Takemoto, Chem. Pharm. Bull., 16, 1605 (1968); M. Yoshihara, C. Yong, C. Zheng, H. Shibuya, Y. Hamamoto, N. Tanaka and I. Kitagawa, Chem. Pharm. Bull., 34, 434 (1986).

7) S. Inayama, J.-F. Gao, K. Harimaya, Y. Iitaka, Y.-T. Guo and T. Kawamata, Chem. Pharm. Bull., 33, 1323 (1985).

8) E. Bunnenberg, C. Djerassi, K. Mislow and A. Moskowitz, J. Am. Chem. Soc., 84, 2823 (1962).

9) Y. Shiobara, Y. Asakawa, M. Kodama, K. Yasuda and T. Takemoto, Phytochemistry, 24, 2629 (1985).

10) J. Endo and H. Itokawa, Symposium Papers, 21 st Symposium on the Chemistry of Natural Products, Sapporo, 1978, p. 401.

11) H. Minato and I. Horibe, J. Chem. Soc. C, 1968, 2131. 
12) P. Main, L. Lessinger, M. M. Woolfson, G. Germain and T. P. Declercq, 1974. MULTAN 74. A System of Computer Programs for the Automatic Solution of Crystal Structures from X-Ray Diffraction Data, Universities of York, England, and Louvin, Belgium.

13) J. B. Hendrickson, J. Am. Chem. Soc., 89, 7036 (1967).

14) G. Snatzke, Tetrahedron, 21, 413, 421, 439 (1965).

15) I. Kouno and N. Kawano, Phytochemistry, 24, 1845 (1985). 